World, 1913-1921, ed. Link, 1982) Johnston carefully explored the truly important and enduring questions about international politics. These writings delve into such issues as the nature of man and of politics, the relationship between self-interest and the common good, the balance between justice and order, the cultural and historical roots of state behavior, the historic struggle in the modern state system between the preservation of state independence and the drive for hegemony, and the bases of durable peace among nations. Drawing from a strong background in American studies in such writings as "Little America-Big America" (Yale Review Fall 1968) and "Security and American Diplomacy" (in America's World Role in the Seventies, ed. Said, 1970), Johnston set out the defining ideas and experiences which shaped America's political culture and set this country apart from all others. His more particular analyses, such as "Franklin Roosevelt and the Wartime Strategy for Peace" (in Traditions and Values: American Diplomacy, 1865-1945, ed. Graebner, 1985), and "The Reagan Revolution and German Democracy" (in Shepherd of Democracy? ed. Hodge \& Nolan, 1992) are carefully set within a broad and illuminating historical and philosophical context. While Johnston regarded the collapse of the Soviet Union and of the ideological threat of communism as a tremendous victory for the United States, he looked at recent trends in American foreign policy with grave concern as, for example, in "Ancient Blood Feuds Underlie Bosnia Issue" (Richmond Times-Dispatch March 10, 1996). He believed that the United States, lacking a moral and cultural compass, was dangerously adrift in the post-Cold War world.

For a great many students and colleagues, the "UVA experience" has been immeasurably diminished by Johnston's premature retirement and untimely death. Although we deeply mourn his passing, we take comfort from the fact that he remains "accessible"-both to us and to new generations of students-through his scholarship. The personal integrity of the man is manifest in the steady judgment and fierce independence of mind that he brought to analysis of political issues. It is especially fitting that he spent most of his career teaching at Thomas Jefferson's university; Johnston was renowned for his commitment to the search for truth irrespective of the personal or political consequences, his devotion to the United States and the Jeffersonian principles of human freedom and individual liberty upon which it was founded, and his "eternal hostility against every form of tyranny over the mind of man." He once noted that the Reagan administration achieved many of its foreign policy successes, such as the INF Treaty, not by accommodating the conventional wisdom on arms control but by firmly resisting very heavy political, diplomatic, and media pressures for the sake of achieving a durable and worthwhile agreement. Johnston followed a broadly similar approach in his scholarship; such writings as "Radical Revisionism and the Disintegration of the American Foreign Policy Consensus" (Orbis, Spring 1976) and "The Containment of John Gaddis" (The National Interest, Winter 1986/87), among a great many others, clearly show that Johnston never trimmed his judgments to bring them into accord with the conventional wisdom of the academy. And because he never sought to be "in fashion" at the expense of the pursuit of truth, his scholarship will never be out of fashion either. Built on the firmest of foundations, Whittle Johnston's scholarship will continue to draw attention, admiration and respect for as long as serious students are engaged in the study of American foreign policy and international politics.

Whittle Johnston often described his family as "the greatest of blessings given to me." $\mathrm{He}$ is survived by Martha Stickney Johnston, his beloved wife and devoted companion of 40 years. "Without Martha", he always insisted, "nothing would have been possible." Johnston is also survived by his daughter Caithness and her husband Russell, his daughter Ruth and her husband Brandt, his son Stafford and his wife Susan and their three children. He is also survived by his brother James and his family. His many friends at UVA and around the country miss him deeply and send their condolences to the Johnston family.

David C. Jordan

Jonathan G. Rice

Robert F. Turner

Michael F. Cairo

University of Virginia

Christina K. Smith

Huntington College

\section{Charles H. Kunsman}

Charles H. Kunsman, Jr., Professor Emeritus of Political Science at San Jose State University, passed away this past summer.

Kunsman was born in the District of Columbia in 1924. He was a triple graduate of the University of California, Berkeley, receiving his bachelor's degree in 1949, a master's in 1955 and his Ph.D in 1963. He served in the Army Air Corp from 1943 to 1946.

Kunsman taught at the University of Nevada, Reno, and served for several sessions as an assistant clerk and researcher of the California State Assembly before his appointment at SJSU in 1961. He retired in early 1996 . His courses were mainly in the field of comparative governments, such as the politics and government of Canada and Scandinavia.

Kunsman's intellectual interest in these subjects never flagged. He continued to research and write papers for scholarly conferences and to travel to observe electoral politics elsewhere. He recently returned from such a visit to British Columbia much excited by a close election campaign. Kunsman was also renowned as a jovial host and for his extensive knowledge of the pubs of Canada and England.

A past president of the Northern California Political Science Association, Kunsman was also a member of several professional organizations and the Saratoga Men's Club.

Theodore Norton

San Jose State University

\section{Sam Postbrief}

Sam Postbrief died on October 17, 1996, at the age of 49 . He was riding his bike late that night near his home in Scituate, Massachusetts, 